\title{
REFORMING THE LIQUIDITY PLANNING PROCESS OF THE NATIONAL BUDGET - STUDY CASE IN SLOVENIA
}

\author{
Mrs. Horjak M \\ Assistant Professor, \\ Ljubljana School of Business \\ marjeta.horjak@gmail.com \\ Mrs. Gartner A \\ Ministry of Finance \\ anja.gartner@gmail.com
}

\begin{abstract}
The constant development of new technologies and tools is forcing organisations to change. In the research part of this article, an example of a concrete process that we had to reform due to the outdated information system that no longer performed the support function for the liquidity planning of the national budget planning process under examination is demonstrated. It includes a presentation of the examined reformation process and the effects of the improvements achieved through the implementation of TAD methodology, the consideration of interviews with the participants in the process, and our own experience gained through cooperation in the development and implementation of the process.

Through our own research - analysis of the reformed process - we found that organisational, substantive, technical, and mental changes are necessary, for they enable the organization an improved and quality business, and it is through the appropriate approach that the employees feel more motivated to perform their daily tasks because inclusion in the renovation process adds value to them according to the opinion of $59 \%$ of the participants in the reformed process. We found that the reformed process is $50 \%$ quicker, saving EUR 3394.80 in costs per year and that the reformed process makes the acquired data and information more accurate, reducing errors by $72 \%$. We found that through the implementation of the examined reformed process, 466 hours of saved time could be used to produce various analyses and reports enabled by the reformed information system of the examined organisation. This also means added value in further forecasting cash flows and carrying out simulations taking into account certain event scenarios that may affect the liquidity of the national budget.
\end{abstract}

Keywords: work process management, business process reform, TAD methodology, process approach 


\section{Introduction}

We live in the age of globalisation, which is bringing modern technologies and forcing us to adapt to changes to keep up with the competition. Organizations are constantly looking for cost-effective improvements for their business processes. Business process management offers organizations a range of methods, techniques, and tools for analyzing, managing, and optimizing their business. It is well worth making use of all these possibilities of modernisation, digitalisation, computerisation, automation, etc., and integrating them into the business processes, for all these new technologies are nowadays of great importance to manage and process the massive amounts of information and data that the global world offers, exchanges, and co-creates, so that we can extract from them those that are important and necessary for the operations of our business (Wynn et al., 2013).

To enforce the execution of the national budget, the Slovene Ministry of Finance establishes a monthly revenue and expenditure plan and manages the liquidity of the national budget (Rules on procedures for the execution of the budget of the Republic of Slovenia, 2016). The business process of national budget liquidity planning consists of several work processes that are the subject matter of this research.

Work processes are carried out in different IT environments. Those IT environments are interconnected, however, errors in the exchange of information, such as incorrect payment forecasts or incorrectly reported data and errors in manual data transcripts, started occurring due to the obsolescence and unsupported applications, which can have a major impact on the liquidity planning process of the national budget. Because of the inability to maintain and upgrade existing applications, malfunctions are occurring and disrupting the support to the work process with existing INFORMATION technology. Obstacles or so-called bottlenecks are being encountered in the execution of the processes, which in turn leads to the inefficiency of the work process. In this particular case, this means that the data are inaccurate, lack transparency, are difficult to obtain, and are reported too late; certain operations need to be carried out manually, the work is duplicated, and there is a greater chance of errors. All of the above is posing a problem or a challenge that moved us to decide for the reform of the process.

The purpose of this article is to present a case study of the optimisation of the liquidity planning process of the national budget through process automation and the achieved effects of improvements. 


\section{Study case - analysis of the existing liquidity planning process of the Slovene national budget and work methodology}

Using the method of our own observation, experience as well as our daily involvement in the execution of the es of the national budget liquidity planning process, we find that cash flow planning is one of the key phases in managing the liquidity of the national budget and is representative of the country's solvency. The national budget planning process consists of several processes. It is based on forecasting the most accurate cash flows data we provide from liquidity plan proposals, liquidity plans, and liquidity plan adjustments and with cash-flows management (National budget liquidity management, 2020). These are the processes that we identify and define below. To analyse the state of the existing process, the data evaluation method will be used to analyse the data obtained from the information systems of the Ministry of Finance, the data obtained from interviews with the users or other participants in the process and the TAD methodology will be applied. As stated by The Damius (2009), the TAD method is based on a tabular representation of the situation.

\subsection{Liquidity plans proposals preparation process and liquidity plans approval (PLN and LN) - AS-IS}

Using the TAD methodology and the derived findings of the analysis of the studied existing process, we identify the key processes the interaction of which is shown in Table 1. We find that the process of preparing liquidity plans proposals and approving liquidity plans is carried out in different areas of business, namely the budget users' groups (BUG [Translator's note: Slovene abbreviation: SPU]), the Treasury Directorate, in particular the Transactions and Liquidity Management Division, the Budget Directorate and the Financial Administration of the Republic of Slovenia [Translator's note: Slovene abbreviation: FURS]. The participants in the process are the proposers of the financial plans, the budget users' administrators, and the treasurers. In summary, FURS [Translator's note: i.e. the Financial Administration of the Republic of Slovenia], DP [Translator's note: National parliament] and SPU [Translator's note: budget users' groups] prepare PLN [Translator's note: Slovene abbreviation for predlog likvidnostnega načrta, i.e. liquidity plan proposal], DZ [Translator's note: Slovene abbreviation for državni zbor, i.e. national assembly] and DP [Translator's note: Slovene abbreviation for državni parlament, i.e. national parliament] deal with PLN and confirm them with an LN [Translator's note: Slovene abbreviation for likvidnostni načrt, i.e. liquidity plan], which is the basis for the preparation of the adjustment of the existing liquidity plan (Rules of Procedure for the execution of the national budget of the Republic of Slovenia, 2016). 
Table 1: Identification of key processes in PLN and approval of LN

\begin{tabular}{|c|c|c|c|}
\hline Business area & Business process/ work process & $\begin{array}{l}\text { Preparation of liquidity } \\
\text { plan proposals }\end{array}$ & $\begin{array}{l}\text { Approval of liquidity plan } \\
\text { proposals }\end{array}$ \\
\hline $\begin{array}{c}\text { Groups of budget } \\
\text { users }\end{array}$ & Liquidity planning & $\mathrm{x}$ & $\mathrm{x}$ \\
\hline $\begin{array}{c}\text { Treasury } \\
\text { Directorate }\end{array}$ & Liquidity management & $\mathrm{x}$ & $\mathrm{x}$ \\
\hline Budget Directorate & Liquidity management & $\mathrm{x}$ & \\
\hline FURS & Liquidity planning & \\
\hline
\end{tabular}

Source: Own (Gartner, 2020)

\section{1.1 TABLE OF PROPERTIES AS-IS and TO-BE}

Table 2 shows a list of operations to be carried out in the existing (AS-IS) reformed PLN preparation process (TO-BE) and the $\mathrm{LN}$ approval process.

Table 2: Table of PLN properties

Table of properties of the existing PLN preparation PROCESS and the approval of LN (AS-IS)

\begin{tabular}{|l|c|c|c|c|c|}
\hline \multirow{2}{*}{ Activity } & $\begin{array}{c}\text { Time } \\
\text { in } \\
\text { min }\end{array}$ & $\begin{array}{c}\text { Cost in } \\
\text { EUR }\end{array}$ & $\begin{array}{c}\text { Time } \\
\text { in } \\
\text { min }\end{array}$ & $\begin{array}{c}\text { Cost in } \\
\text { EUR }\end{array}$ & $\begin{array}{c}\text { Savings in } \\
\%\end{array}$ \\
\hline Initialising PLN documents & 5 & 0,61 & 0 & 0,00 & -100 \\
\hline $\begin{array}{l}\text { Overview and data preparation for } \\
\text { entering PLN }\end{array}$ & 85 & 10,33 & 40 & 4,86 & -53 \\
\hline Entering and arranging a PLN document & 37 & 4,50 & 20 & 2,43 & -46 \\
\hline PLN refusal & 10 & 1,22 & 5 & 0,61 & -50 \\
\hline Data import/export & 10 & 1,22 & 0 & 0,00 & -100 \\
\hline PLN approval & 5 & 0,61 & 3 & 0,36 & -40 \\
\hline $\begin{array}{l}\text { Storage of data in a SULP [Translator's } \\
\text { note: Slovene abbreviation for sistem za } \\
\text { upravljanje likvidnosti proračuna, i.e. } \\
\text { budget liquidity management system] } \\
\text { database }\end{array}$ & 5 & 0,61 & 0 & 0,00 & -100 \\
\hline $\begin{array}{l}\text { Transfer of data from PLN to LN and } \\
\text { KLN [Translator's note: Slovene } \\
\text { abbreviation for korigiran likvidnostni } \\
\text { načrt, i.e. adjusted liquidity plan] }\end{array}$ & 10 & 1,22 & 0 & 0,00 & -100 \\
\hline Sum & 167 & 20,32 & 68 & 8,26 & -59 \\
\hline
\end{tabular}

Table of properties of the reformed PLN preparation PROCESS and the approval of PLN (TO-BE)

\begin{tabular}{l} 
al of LN \\
\begin{tabular}{l|l|} 
Approval of liquidity plan \\
proposals
\end{tabular} \\
\hline
\end{tabular}


The operations in Table 2 were evaluated according to the duration expressed in minutes and the costs expressed in EUR. Data were obtained through interviews with 27 users and participants in the process, but we also used a method of observation or recording of measurements during the process execution and the method of evaluation of data from the information systems of the Ministry of finance to obtain our data. The data for the reformed process is our estimate of the expected time and costs after the completion of the reform process, which we have produced through our observations and experience. We determined the average job level of the participants in the process that perform individual operations. We calculated the average hourly rate of the average monthly salary on the determined workplace-

We found through the method of our observation that the existing process that we studied is carried out once a month, i.e. 12 times in a year. The total duration of all key operations in the preparation process of the liquidity plan proposal and the liquidity plan approval is approximately 3 hours, and the cost of the key operations of the process is EUR 20,32. Based on our observations and experience, we estimate that the process reform will save about $59 \%$ of time and money. In the evaluation, we envisaged that some operations would be discontinued because we determined with the method of our observations and experience gained through the daily involvement in the examined process that in the reformed process their execution will no longer be necessary and other operations will be carried out in less time.

\subsection{The process of communicating $\mathrm{LN}$ adjustments}

From Table 3 below it can be seen that the key processes take place in 4 business areas, namely the SPU, DP, FURS, and DZ. The participants in the process are PFN [Translator's note: Slovene abbreviation for predlagatelji finančnega načrta, i.e. the proposers of the financial plan], budget user administrators, and treasurers.

Table 3: Identification of KLN processes

\begin{tabular}{|c|c|c|c|}
\hline Business area & $\begin{array}{l}\text { Business process/ work } \\
\text { process }\end{array}$ & $\begin{array}{l}\text { Communication of } \\
\text { liquidity plan adjustments }\end{array}$ & $\begin{array}{l}\text { Approval of applications } \\
\text { for an increase in the } \\
\text { monthly liquidity plan }\end{array}$ \\
\hline SPU & Liquidity planning & $\mathrm{x}$ & $\mathrm{x}$ \\
\hline DP & Liquidity management & $\mathrm{x}$ & $\mathrm{x}$ \\
\hline DZ & Liquidity management & $\mathrm{x}$ & \\
\hline FURS & Liquidity planning & \\
\hline
\end{tabular}

Source: Own (Gartner, 2020) 
The KLN process starts by first verifying the data in the SPU (the forecasted daily liquidity plan and the estimated actual payments are being compared) that are already apparent from the KLN document that is located in the MFERAC system [Translator's note: Slovene abbreviation for enoten računovodski sistem za izvrševanje državnega proračuna, i.e. unified accounting system for the execution of the national budget]. Because users are familiar with the fact that the code list that translates economic classification into liquidity items no longer works, they know that they have to use a different report, which is also available in the MFEARAC system, to obtain accurate data. They then compile all this data and edit the KLN document, and finally approve it to the conforming status. Due to a non-unified correction communication system (PU [Translator's note: Slovene abbreviation for proračunski uporabnik, i.e. budget user] level, SPUV), some users have more work than others. SPU or PFN prepare the correction in the IS [Translator's note: Slovene abbreviation for informacijski sistem, i.e. information system] MFERAC. Provided that the correction increases the LN (application for the LN increase), the KLN document is forwarded for consideration into the DP. This is regulated with statuses. The PU administrator examines the application and approves or rejects it by adjusting its status to conform with the situation. If the application is rejected, it shall be returned to the PFN for preparation, and if the application is approved, it shall be forwarded to the DZ for consideration, where the Treasurer takes a final decision by approving the document or application by confirming the appropriate status. Adjustment of revenues (this is a particular type of tax revenue, most often value-added tax (VAT) or annual income tax calculation) is sent by FURS via e-mail to the DZ. The Treasurer manually enters the adjusted information into the auxiliary database SULP. All data on adjustments prepared by PFN are located in IS MFERAC because the SULP database does not support automatic data import. The treasurer uses a report from the MFERAC system to record or register all the prepared adjustments of the SPU and manually enters them into the auxiliary database SULP. He then imports the adjustment data from the auxiliary SULP database into the SULP database using the process, where the data are only transferred. For the new situation to be reflected, another process should also be initiated to sum the data. Because manual entries often lead to errors and any deviations need to be checked in advance with a prestandardised report. In case there are some deviations, the Treasurer must repeat the process of manual corrections and data imports.

\subsubsection{TABLE OF PROPERTIES AS-IS and TO-BE}

Table 4 is demonstrating a list of operations carried out in the existing and the reformed PROCESS of reporting the LN adjustments, which we prepared based on our observations and experience in daily involvement in the studied process, and evaluated them according to the duration expressed in minutes and the costs expressed in EUR. Data were obtained through interviews with users or process participants, and for obtaining the data we also used the method of our recording of measurements during the execution of the process and 
the method of evaluation of information systems data of the Ministry of Finance. The data of the reformed process represent our estimate of the expected time and costs after the completion of the process reform. Afterwards, we first determined the average step of the grade of the post of the process participants who perform the operations. We calculated the average hourly rate of the average monthly salary on the determined workplace.

We have concluded that the following operations presented in Table 4 are key to the examined process.

Table 4: KLN properties table

\begin{tabular}{|c|c|c|c|c|c|}
\hline \multicolumn{3}{|c|}{$\begin{array}{l}\text { Table of properties for the existing LN adjustments } \\
\text { reporting PROCESS (AS-IS) }\end{array}$} & \multicolumn{3}{|c|}{$\begin{array}{l}\text { Table of properties for the } \\
\text { reformed LN adjustments } \\
\text { reporting PROCESS (TO- } \\
\text { BE) }\end{array}$} \\
\hline Operation & $\begin{array}{l}\text { Time } \\
\text { in } \mathrm{min}\end{array}$ & $\begin{array}{l}\text { Cost in } \\
\text { EUR }\end{array}$ & $\begin{array}{l}\text { Time } \\
\text { in min }\end{array}$ & $\begin{array}{l}\text { Cost in } \\
\text { EUR }\end{array}$ & $\begin{array}{c}\text { Savings in } \\
\%\end{array}$ \\
\hline Data overview & 19 & 2,31 & 10 & 1,22 & -100 \\
\hline $\begin{array}{l}\text { Review and organisation of the KLN } \\
\text { document for PU/SPU }\end{array}$ & 20 & 2,43 & 10 & 1,22 & -50 \\
\hline Increase application preparation & 5 & 0,61 & 2 & 0,24 & -60 \\
\hline $\begin{array}{l}\text { Approval of the application for an } \\
\text { increase }\end{array}$ & 5 & 0,61 & 5 & 0,61 & 0 \\
\hline $\begin{array}{l}\text { Overview and a list of submitted } \\
\text { adjustments }\end{array}$ & 30 & 3,65 & 0 & 0 & -100 \\
\hline $\begin{array}{l}\text { Entering the data into the auxiliary } \\
\text { SULP database }\end{array}$ & 25 & 3,04 & 0 & 0 & -100 \\
\hline $\begin{array}{l}\text { Importing the data into the central } \\
\text { SULP database }\end{array}$ & 10 & 1,22 & 0 & 0 & -100 \\
\hline Sum & 114 & 13,87 & 27 & 3,29 & -76 \\
\hline
\end{tabular}


We found that the existing examined process is carried out daily. The total duration of all key operations of the existing liquidity plan adjustment reporting process is approximately 2 hours and the cost of key process operations is EUR 13,87. We estimate that the reform of the process will save about $76 \%$ of the time and money. In our evaluation, we assumed that some operations would be discontinued, as we found that in the reformed process their execution would no longer be necessary.

\subsection{Cash-flow management process}

Through our observation and daily involvement in the examined process, we have concluded that the cash-flows management process is carried out in the Treasury directorate. The process correlates with the liquidity planning process, for all the data obtained in this process directly influence the following decisions in cash-flow management. The participants in the process are treasurers. The areas of events included in the examined process are shown in Table 5.

Table 5: Identification of cash-flow management processes

\begin{tabular}{|c|c|c|c|c|}
\hline $\begin{array}{c}\text { Business } \\
\text { area }\end{array}$ & $\begin{array}{l}\text { Business process/ work } \\
\text { process }\end{array}$ & $\begin{array}{l}\text { Data import from } \\
\text { the existing } \\
\text { sources }\end{array}$ & $\begin{array}{l}\text { Data } \\
\text { reconciliation }\end{array}$ & $\begin{array}{l}\text { Data } \\
\text { preparation }\end{array}$ \\
\hline \multirow{2}{*}{ DZ } & Liquidity planning & $\mathrm{x}$ & $\mathrm{x}$ & $\mathrm{x}$ \\
\cline { 2 - 5 } & Liquidity management & $\mathrm{x}$ & $\mathrm{x}$ & $\mathrm{x}$ \\
\hline
\end{tabular}

Source: Own (Gartner, 2020)

\subsubsection{TABLE OF PROPERTIES AS-IS and TO-BE}

Table 6 shows a list of operations carried out in the existing and the reformed cash-flows management process, which we created by using our observations and experience gained through the daily involvement in the examined process and were evaluated according to the duration expressed in minutes and the cost expressed in EUR. The data were obtained through our recording of measurements during the execution of the process and with the help of the data evaluation of information systems of the Ministry of finance. The data of the reformed process represent our estimate of the expected time and costs after the completion of the process reform. We determined the average job level of the participants in the process that perform individual operations. We calculated the average hourly rate of the average monthly salary on the determined workplace. In Table 6 , average values are used. 
Table 6: Table of properties for cash-flow management

\begin{tabular}{|c|c|c|c|c|c|}
\hline \multicolumn{3}{|c|}{$\begin{array}{l}\text { Table of properties for the existing cash-flow } \\
\text { management PROCESS (AS-IS) }\end{array}$} & \multicolumn{3}{|c|}{$\begin{array}{l}\text { Table of properties for the } \\
\text { reformed cash-flow } \\
\text { management PROCESS (TO- } \\
\text { BE) }\end{array}$} \\
\hline Operation & $\begin{array}{l}\text { Time in } \\
\text { min }\end{array}$ & $\begin{array}{l}\text { Cost in } \\
\text { EUR }\end{array}$ & $\begin{array}{c}\text { Time in } \\
\text { min }\end{array}$ & $\begin{array}{l}\text { Cost in } \\
\text { EUR }\end{array}$ & $\begin{array}{c}\text { Savings in } \\
\%\end{array}$ \\
\hline Data collection and review & 30 & 3,65 & 10 & 1,22 & -67 \\
\hline Entering the data & 20 & 2,43 & 10 & 1,22 & -50 \\
\hline Data import/export & 10 & 1,22 & 0 & 0 & -100 \\
\hline Sum & 60 & 7,30 & 20 & 2,44 & -67 \\
\hline
\end{tabular}

We found that the total duration of all key operations of the cash-flow management process is approximately 1 hour and the cost of the key operations of the process is EUR 7.29. We estimate that the process reform will save about $67 \%$ of the time and money. In our estimates, we took into account that some operations will be discontinued as we found that in the reformed process their execution will no longer be necessary and other operations will be carried out instead in less time.

\subsubsection{BPMN model - graphic notation of an existing process (AS-IS)}

We used the ARIS tool to create a graphical demonstration of the execution of the existing cash-flow management process model (Figure 1).

Figure 1: BPMN of the existing cash-flow management process

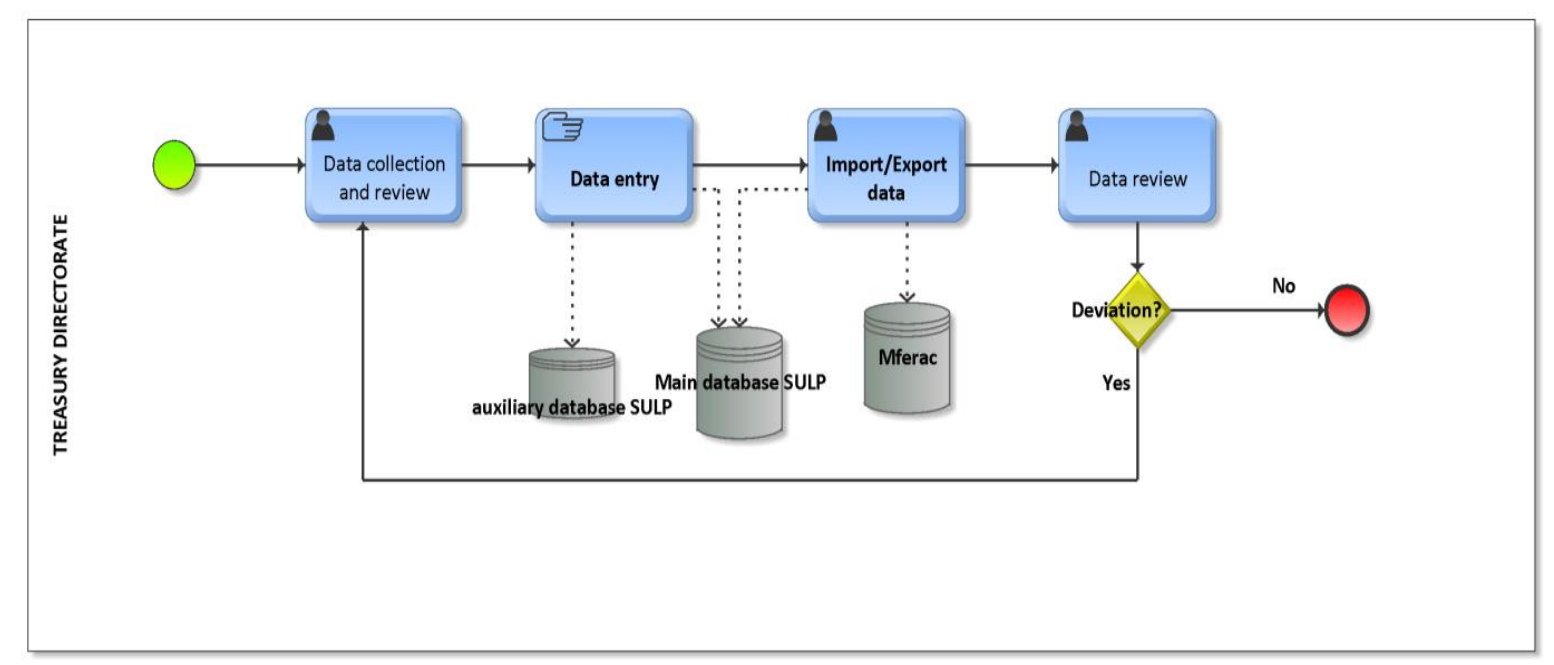

Source: ARIS Self-Display (Gartner, 2020) 


\section{Analysis of the reformed national budget liquidity planning process (i.e. PLN) and work methodology}

For the analysis of the reformed cash-flow planning process, we use the third phase of the TAD methodology to present the effects of the improvements by comparing the operations carried out in the existing AS-IS process and the reformed TO-BE process (Damij, 2009). To evaluate the execution of work processes we used the method of our observation and experience, the analysis of the data obtained through interviews with the participants of the processes, and the method of evaluation of data obtained from the information systems of the Ministry of finance. In the following, we are presenting the analysis of each of the reformed processes.

\subsection{Liquidity plan proposal preparation process and liquidity plan approval process}

It can be identified from the reformed model of the PLN preparation and the LN approval process shows that here, in contrast to the AS-IS process, the flow of information or data between the participants in the process passes through a single MFERAC system. Manual operations (triggering initialisation processes, import, export, entry of data) were replaced by automated service processes carried out immediately with any change in the system in real-time, which in turn means that the number of operations for the process participants has decreased, which we have found using the method of our observation, experience gained through our daily involvement in the examined process, the method of recording the measurements and the evaluation of data from the information systems of the Ministry of finance. Furthermore, we note that in the TO-BE process, all data are automatically reflected in all modules of the Liquidity planning, which means less error potential compared to the existing process.

We have noticed that in addition to changing the operations of the existing process, the content has changed in the reformed process as well. In the AS-IS process, users were preparing data at the level of liquidity items, which meant additional data collection and grouping as they were obtained from the existing MFERAC system, which saved them in a different format or inappropriately grouped the liquidity items. In the TO-BE process, users could already obtain the relevant data from the PLN document as they were no longer grouped into liquidity items but have been unified to the level of economic classification used throughout the MFERAC system. This change was introduced to obtain as accurate data as possible for the manager and reduce the time of users to review, collect and prepare the data. Below, Figure 2 shows the model of a reformed process of preparing liquidity plans proposals and approving liquidity plans. 


\subsubsection{BPMN model - graphic notation of the reformed process}

Figure 2: BPMN model of the reformed PLN process

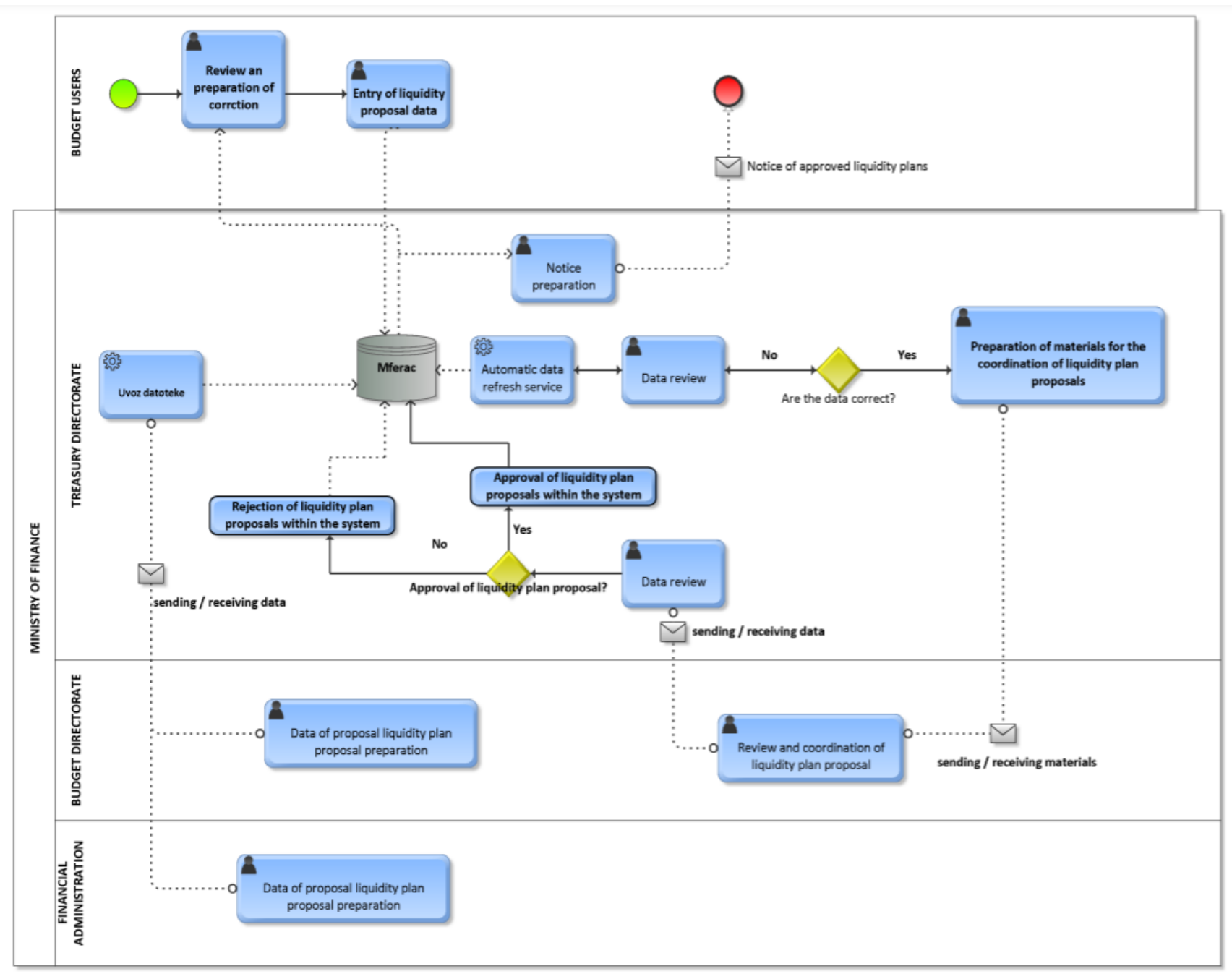

Source: ARIS Self-Display (Gartner, 2020)

\subsection{Liquidity plan adjustments reporting process}

The main change to the reformed liquidity plan adjustments reporting process (KLN) is that, compared to the AS-IS process, the communication between the participants only passes through the MFERAC system. Manual operations (manual entries, import, and export of data) were also replaced by automated service processes carried out immediately with any change in the system in real-time, which in turn means that the number of operations for process participants has decreased, which we were able to determine by using the method of our observation and experience gained through the daily involvement in the examined process. We also found that in the TO-BE process, all data are automatically reflected in all modules of the Liquidity planning area, which means that there is less error potential. In addition to the changed operations in the TO-BE process, we found that minor substantive changes were also introduced: In contrast to the users of 
the AS-IS process, users in the TO-BE process can report an adjustment already for the 1st day of the month, and do not have to wait till the 10th day of the month anymore. This change was introduced to obtain the most accurate data possible for the manager and reduce the number of corrections of the deviations of realised payments from those announced at the end of the month. With the introduction of the economic classification, the KLN module now also requires that the data are registered and shown already in the KLN document, which means less time spent on preparation and collection of data for the users of the system. Figure 3 shows the model of the reformed liquidity plan adjustments reporting process.

\subsubsection{BPMN Model - graphic notation of the reformed process (TO-BE)}

Figure 3: BPMN of the reformed KLN process

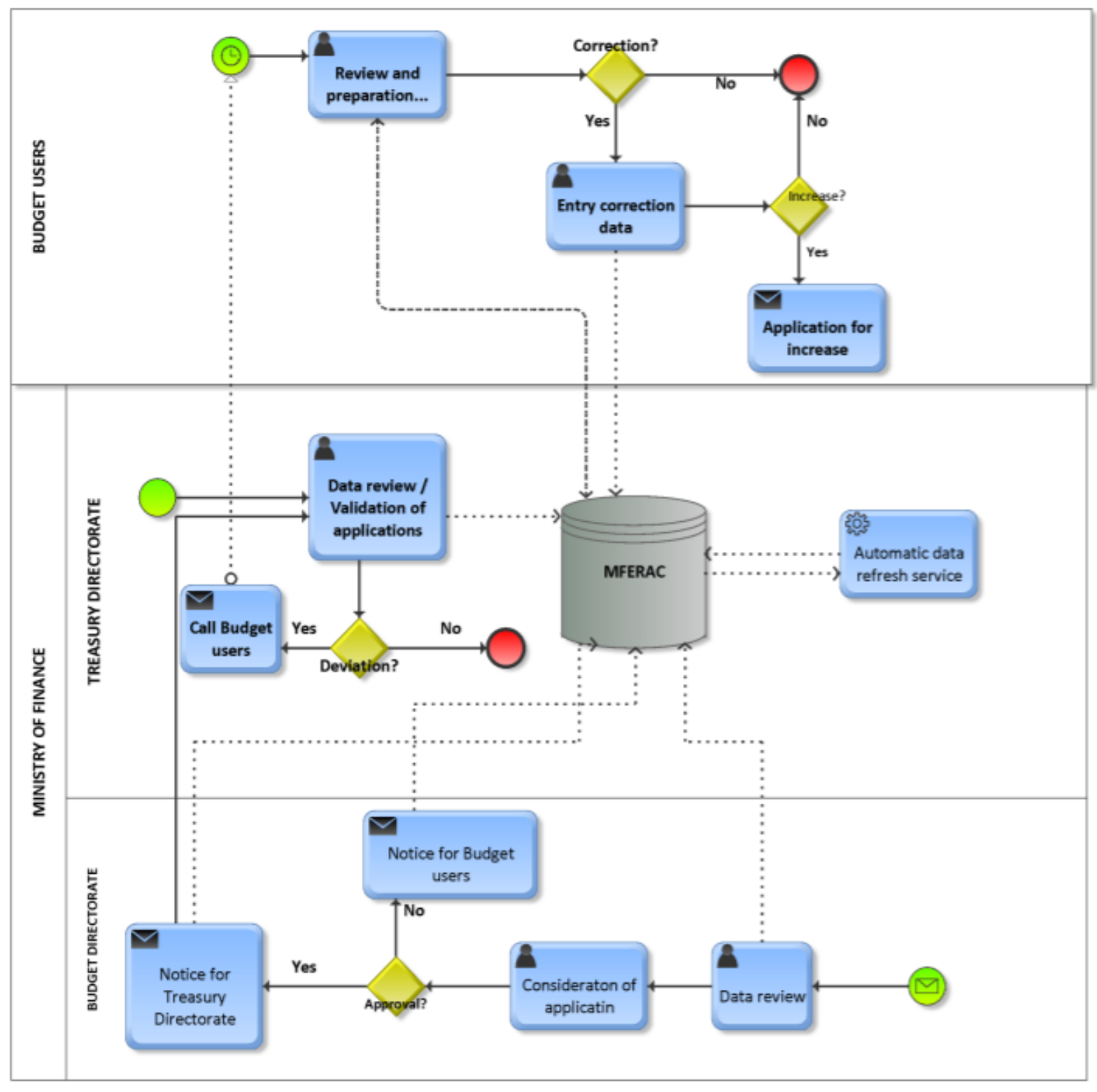

Source: ARIS Self-Display (Gartner, 2020) 


\subsection{Cash-flow management process}

Using our observation and experience gained through the daily involvement in the examined process and our recording of measurements and the method of evaluation of information systems data, we found that most changes, both substantive, procedural, and technical, were made in the process of cash flows management. We found that in the existing AS-IS process, the main support information system was the database SULP, which has been in use since 1999, which means that with the reform the cash flow management process will be moved to a new system environment for the first time. We note that most time has been spent on the production of the cash flows module, for it is a comprehensive and complex system, and has at the same time also a key support function for the planning, monitoring, and management of cash flows of the national budget. A key substantive change is also the database at the level of a single unified economic classification, and no longer at the level of liquidity items. In addition, the TO-BE process is wholly executed in a new web environment in the MFERAC system, and no longer in the SULP database. It is a very different environment, and while it still provides the required and necessary functionality, how individual operations are carried out in the process has changed. As we have already noted, cash flow in the existing AS-IS process consists of various data sources that were mainly imported from the existing MFERAC system, the auxiliary database SULP, and the data that were entered manually. However, in the reformed TO-BE process, we find that the data again consists of different data sources, which are automatically reflected in the Cash flows module, since all data are now located in a single unified MFERAC system. We find that the new system enables multiple users to record simultaneously, provides an audit trail of the modified data, preset calculations are built in to show data according to the user's request, and the settings can be edited. We find that it is possible to plan cash flows for the future based on the dynamics of cash inflows and outflows of the previous years. A key part is that the PLN and KLN modules are now connected to the Cash flows module, which means that the data are transferred automatically across the modules. For example, in the AS-IS process, PFN prepared a liquidity plan proposal, however, for this information to also be seen in the SULP database, the Treasurer had to manually initiate the data import process. In the TOBE process, the PLN data are transferred automatically. The same applies to the data of the reported adjustments, the realisation of revenues and expenditures, and the claims, in short: all the data constituting the cash flow.

We also noted that the modifications to the existing execution of the cash flow management process were intended to provide a stable support information system to obtain the most accurate data to facilitate the planning of the liquidity of the national budget.

The revised process model in Figure 14 shows the communication flow of data through a single MFERAC system with automated data refresh procedures and possible manual corrections. 


\subsubsection{BPMN model - graphic notation of the reformed process}

Figure 4: BPMN of the reformed cash flow management process

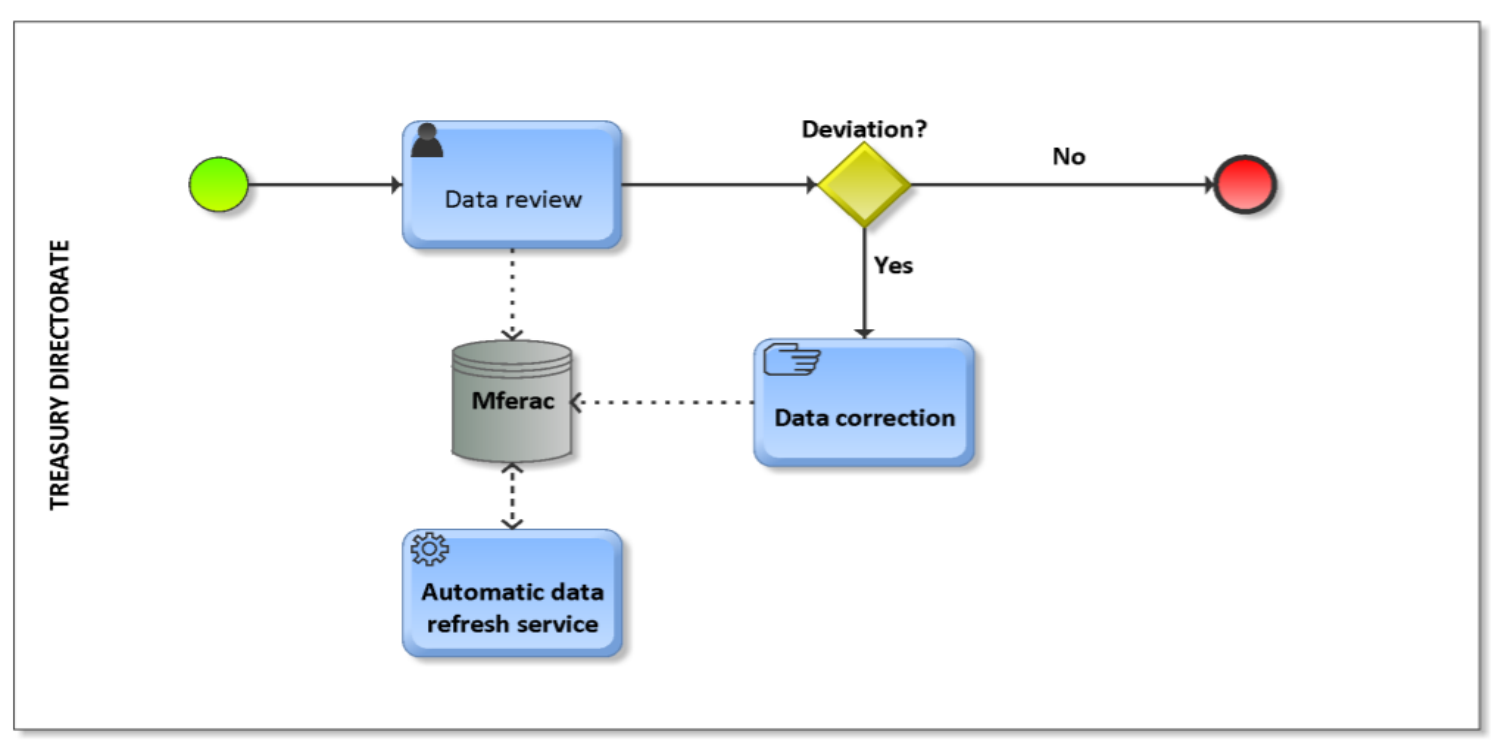

Source: ARIS Self-Display (Gartner, 2020)

\section{$4 \quad$ Results}

To evaluate the presentation of the effects of improvements in the reformed national budget planning process, we used the second part of the third phase of the TAD methodology, i.e. the effects of the improvements that are also shown in the tables below. In addition to the TAD methodology, we came to the effects of process improvements by interviewing process participants, using the method of observation and our own experience, recording of measurements and evaluation of data of information systems if the Slovene Ministry of finance, and the preparation of calculations of the data obtained in the implementation of the examined processes. We determined the average job level of the participants in the process that perform individual operations. We calculated the average hourly rate of the average monthly salary of the determined work post and obtained the data on the duration of each activity.

Table 7 shows the effects of the time and cost of executing the individual operations of the reformed process of preparing the liquidity plan proposal and approving the liquidity plan. We used average values. 
Table 7: Effects of improvements to the reformed PLN preparation and LN approval process

\begin{tabular}{|c|c|c|c|c|c|c|c|}
\hline \multicolumn{3}{|c|}{$\begin{array}{l}\text { Table of properties of the existing PLN } \\
\text { preparation PROCESS and the } \\
\text { approval of the LN (AS-IS) }\end{array}$} & \multicolumn{2}{|c|}{$\begin{array}{l}\text { Table of } \\
\text { properties of } \\
\text { the reformed } \\
\text { PLN } \\
\text { preparation } \\
\text { PROCESS } \\
\text { and the LN } \\
\text { approval of } \\
\text { the LN (TO- } \\
\text { BE) }\end{array}$} & \multirow[t]{2}{*}{$\begin{array}{c}\text { The time } \\
\text { difference } \\
\text { in min }\end{array}$} & \multirow[t]{2}{*}{$\begin{array}{c}\text { Costs } \\
\text { difference } \\
\text { in EUR }\end{array}$} & \multirow[t]{2}{*}{$\begin{array}{c}\text { Costs } \\
\text { difference } \\
\text { in \% } \\
\text { (TO-BE) }\end{array}$} \\
\hline Operation & $\begin{array}{l}\text { Time } \\
\text { in } \\
\text { min }\end{array}$ & $\begin{array}{l}\text { Cost in } \\
\text { EUR }\end{array}$ & $\begin{array}{l}\text { Time } \\
\text { in } \\
\text { min }\end{array}$ & $\begin{array}{c}\text { Cost in } \\
\text { EUR }\end{array}$ & & & \\
\hline $\begin{array}{l}\text { Initialising PLN } \\
\text { documents }\end{array}$ & 5 & 0,61 & 0 & 0,00 & -5 & $-0,61$ & -100 \\
\hline $\begin{array}{l}\text { Overview and data } \\
\text { preparation for entering } \\
\text { PLN }\end{array}$ & 85 & 10,33 & 82 & 9,96 & -3 & $-0,36$ & -4 \\
\hline $\begin{array}{l}\text { Entering and organising } \\
\text { a PLN document }\end{array}$ & 37 & 4,50 & 35 & 4,25 & -2 & $-0,24$ & -5 \\
\hline PLN refusal & 10 & 1,22 & 5 & 0,61 & -5 & $-0,61$ & -50 \\
\hline Data import/export & 10 & 1,22 & 0 & 0,00 & -10 & $-1,22$ & -100 \\
\hline PLN approval & 5 & 0,61 & 5 & 0,61 & 0 & 0,00 & 0 \\
\hline $\begin{array}{l}\text { Storage of data in a } \\
\text { SULP [Translator's } \\
\text { note: Slovene } \\
\text { abbreviation for sistem } \\
\text { za upravljanje } \\
\text { likvidnosti proračuna, } \\
\text { i.e. budget liquidity } \\
\text { management system] } \\
\text { database }\end{array}$ & 5 & 0,61 & 0 & 0,00 & -5 & $-0,61$ & -100 \\
\hline $\begin{array}{l}\text { Transfer of data from } \\
\text { PLN to LN and KLN } \\
\text { [Translator's note: } \\
\text { Slovene abbreviation for } \\
\text { korigiran likvidnostni } \\
\text { načrt, i.e. adjusted } \\
\text { liquidity plan] }\end{array}$ & 10 & 1,22 & 0 & 0,00 & -10 & $-1,22$ & -100 \\
\hline Sum & 167 & 20,29 & 127 & 15,43 & -40 & $-4,86$ & -24 \\
\hline
\end{tabular}


After analysing the results obtained from Table 7, we conclude that 4 manual operations (triggering the initialisation process, data import and export procedures, data storage process, and data transfer process) were discontinued the process reform. The implementation of the TO-BE process reduced the time consumption by $24 \%$, which is $35 \%$ less than predicted in the estimated expected duration of the TO-BE process (Table 4). We assume that the discrepancy between the assessed and the actual duration of the reformed process occurred because the TO-BE process is still being developed. We have found that the production of the reformed MFERAC system is currently using the best version of the module, however, still not as it was planned before the start of the reform. This can be taken into account as one of the limitations of the examination of the reformed process. We found that the process reform aimed to achieve at least an estimate of the expected time and costs savings, and we assume that this may be achievable if we continue the system and process development. We nevertheless note that the process of PLN preparation and LN approval has been reduced by 40 minutes, which means a EUR 4.86 lower cost. We also found that the process is carried out once a month, i.e. 12 times a year, and thus 8 hours less in a year, which means EUR 58.12 fewer costs per year, as shown in Table 10.

Table 8 shows the effects of the time and costs of the execution of individual operations in the reformed liquidity plan adjustment process. We used average values.

Table 8: Effects of improvements in the reformed adjustment reporting process

\begin{tabular}{|c|c|c|c|c|c|c|c|}
\hline \multicolumn{3}{|c|}{$\begin{array}{l}\text { Table of properties of the existing adjustments } \\
\text { reporting PROCESS (AS-IS) }\end{array}$} & \multicolumn{2}{|c|}{$\begin{array}{l}\text { Table of } \\
\text { properties of the } \\
\text { reformed } \\
\text { adjustments } \\
\text { reporting } \\
\text { PROCESS (TO- } \\
\text { BE) }\end{array}$} & \multirow[t]{2}{*}{$\begin{array}{l}\text { The time } \\
\text { difference } \\
\text { in min }\end{array}$} & \multirow[t]{2}{*}{$\begin{array}{c}\text { Costs } \\
\text { difference } \\
\text { in EUR }\end{array}$} & \multirow[t]{2}{*}{$\begin{array}{c}\text { Costs } \\
\text { difference } \\
\text { in \% (TO- } \\
\text { BE) }\end{array}$} \\
\hline Operation & $\begin{array}{c}\text { Time in } \\
\text { min }\end{array}$ & $\begin{array}{l}\text { Cost in } \\
\text { EUR }\end{array}$ & $\begin{array}{c}\text { Time in } \\
\text { min }\end{array}$ & $\begin{array}{l}\text { Cost in } \\
\text { EUR }\end{array}$ & & & \\
\hline Data overview & 19 & 2,31 & 17 & 2,07 & -2 & $-0,24$ & -11 \\
\hline $\begin{array}{l}\text { Review and organisation of the } \\
\text { KLN document for PU }\end{array}$ & 20 & 2,43 & 10 & 1,22 & -10 & $-1,22$ & -50 \\
\hline Increase application preparation & 5 & 0,61 & 3 & 0,36 & -2 & $-0,24$ & -40 \\
\hline $\begin{array}{l}\text { Approval of the application for } \\
\text { an increase }\end{array}$ & 5 & 0,61 & 5 & 0,61 & 0 & 0,00 & 0 \\
\hline $\begin{array}{l}\text { Overview and a list of } \\
\text { submitted adjustments }\end{array}$ & 30 & 3,65 & 10 & 1,22 & -20 & $-2,43$ & -67 \\
\hline $\begin{array}{l}\text { Entering the data into the } \\
\text { auxiliary SULP database }\end{array}$ & 25 & 3,04 & 0 & 0,00 & -25 & $-3,04$ & -100 \\
\hline $\begin{array}{l}\text { Importing the data into the } \\
\text { central SULP database }\end{array}$ & 10 & 1,22 & 0 & 0,00 & -10 & $-1,22$ & -100 \\
\hline Sum & 114 & 13,85 & 45 & 5,47 & -69 & $-8,38$ & -61 \\
\hline
\end{tabular}

Source: Own (Gartner, 2020) 
By analysing the results obtained from Table 8, we conclude that on average the TO-BE process is shorter by as much as $61 \%$, which is only $15 \%$ more than we predicted in our estimated duration of the reformed process (Table 6). The shorter execution time means EUR 8.38 fewer costs. We found that the process is carried out every day, which means EUR 175.98 fewer costs per month, which means EUR 2,111.76 fewer costs per year (Table 12). We note that the process of reporting LN TO-BE adjustments is still being developed and does not yet represent the situation planned before the reform.

Table 9 shows the effects of the time and cost of execution for each of the operations of the reformed cash flow management process. We used average values.

Table 9: Effects of improvements to the reformed cash flow management process

\begin{tabular}{|c|c|c|c|c|c|c|c|}
\hline \multicolumn{3}{|c|}{$\begin{array}{l}\text { Table of properties of the existing cash flow } \\
\text { management PROCESS (AS-IS) }\end{array}$} & \multicolumn{2}{|c|}{$\begin{array}{l}\text { Table of } \\
\text { properties for } \\
\text { the reformed } \\
\text { cash-flow } \\
\text { management } \\
\text { PROCESS (TO- } \\
\text { BE) }\end{array}$} & \multirow[t]{2}{*}{$\begin{array}{l}\text { The time } \\
\text { difference } \\
\text { in min }\end{array}$} & \multirow[t]{2}{*}{$\begin{array}{c}\text { Costs } \\
\text { difference } \\
\text { in EUR }\end{array}$} & \multirow[t]{2}{*}{$\begin{array}{c}\text { Costs } \\
\text { difference } \\
\text { in \% } \\
\text { (TO-BE) }\end{array}$} \\
\hline Operation & $\begin{array}{l}\text { Time } \\
\text { in min }\end{array}$ & $\begin{array}{l}\text { Cost in } \\
\text { EUR }\end{array}$ & $\begin{array}{l}\text { Time } \\
\text { in min }\end{array}$ & $\begin{array}{l}\text { Cost in } \\
\text { EUR }\end{array}$ & & & \\
\hline Data collection and review & 30 & 3,65 & 15 & 1,82 & -15 & $-1,82$ & 50 \\
\hline Entering the data & 20 & 2,43 & 5 & 0,61 & -15 & $-1,82$ & -75 \\
\hline Data import/export & 10 & 1,22 & 0 & 0,00 & -10 & $-1,22$ & -100 \\
\hline Sum & 60 & 7,29 & 20 & 2,43 & -40 & $-4,86$ & -67 \\
\hline
\end{tabular}

Source: Own (Gartner, 2020)

By analysing the obtained results, which are shown in Table 9, we find that the execution of the process has been reduced by $67 \%$, just as announced in the estimated expected duration of the TO-BE process (Table 8). We found that the process is carried out every day, which means EUR 102.06 fewer costs per month and EUR 1,224.72 fewer costs per year. We also found that the process or support information system is currently in development and that the existing version of the cash flows module, which is in production, does not yet represent the situation that was planned before the start of the reform.

Table 10 shows the annual effects of the reformed national budget liquidity planning process. We used average values. 
Table 10: Annual effects of the reformed process

\begin{tabular}{|l|c|c|c|c|c|l|}
\hline \multicolumn{7}{|c|}{ The annual impact of the TO-BE national budget liquidity planning PROCESS } \\
\hline Process & $\begin{array}{c}\text { No. of } \\
\text { executions }\end{array}$ & $\begin{array}{c}\text { Time } \\
\text { difference } \\
\text { in min }\end{array}$ & $\begin{array}{c}\text { Costs } \\
\text { difference } \\
\text { in EUR }\end{array}$ & $\begin{array}{c}\text { Costs } \\
\text { difference } \\
\text { in \% }\end{array}$ & $\begin{array}{l}\text { Annual } \\
\text { savings in } \\
\text { hours }\end{array}$ & $\begin{array}{l}\text { Annual } \\
\text { cost } \\
\text { savings in } \\
\text { EUR }\end{array}$ \\
\hline $\begin{array}{l}\text { PLN preparation and } \\
\text { LN approval process }\end{array}$ & 12 & -40 & $-4,86$ & -24 & -8 & $-58,32$ \\
\hline $\begin{array}{l}\text { LN adjustment } \\
\text { process }\end{array}$ & 252 & -69 & $-8,38$ & -61 & -290 & $-2.111,76$ \\
\hline $\begin{array}{l}\text { Cash-flow } \\
\text { management process }\end{array}$ & 252 & -40 & $-4,86$ & -67 & -168 & $-1.224,72$ \\
\hline Sum & 516 & -149 & $-18,11$ & -51 & -466 & $-3.394,80$ \\
\hline
\end{tabular}

By analysing the data obtained from the interviews of the participants and by using the method of our observation and experience and recording measurements during the execution of the examined process and the evaluation from the information systems of the Ministry of finance we found that $59 \%$ of users or participants in the TO-BE process were satisfied with the reform and had the opportunity to participate in the reform (question 6). Users listed some advantages of the reformed process: $22 \%$ of users believe that user support is well-established, $19 \%$ of users see an advantage in the introduction of an economic classification that replaced the use of liquidity items, which consequently reduces the time users can review, collect and prepare data. 19\% of the users see the advantage of the reformed in particular in the introduction of the data entry level at the SPU level, 9\% of users see the advantage in the automatic coordination of dynamics on the last day of the month, which reduces their processing time, and $9 \%$ of the users think that the reformed system is more transparent. $9 \%$ of users also believe that the reform is reducing the process execution time, $6 \%$ of users are satisfied with the possible reporting of adjustments for the 1st day of the month, and not only for the 10th day of the month, as was the case in the AS-IS process. $3 \%$ of the users see the advantage in introducing a graphical representation of the discrepancies between the announced liquidity plan and the actual realisation of payments. In the following, we note that $41 \%$ of users have submitted proposals for a change (question 6) or an improvement of the reformed process, which the organisation will be able to take into account in further development.

Furthermore, we also note that KLN data are automatically reflected in the Cash flows module, which for us, i.e. the managers, means immediate access to up-to-date data without manual inputs and without errors. We found that the main advantage of the cash flow management process is that the data is retrieved automatically from the sources from which cash flow is made up. We found that manual data entry operations were automated, which means that the data is imported from a file or shown directly from the existing sources of the MFERAC information system, where the Cash flows module is located, 
which means that the data contains $72 \%$ fewer errors compared to the AS-IS process. We found that the data are regulated at the level of the economic classification, and no longer at the level of liquidity items, as is the case in the AS-IS process. By comparing data in the information systems of the existing SULP database and the reformed MFERAC, we found that the data are more accurate, which means $18 \%$ less discrepancy between the planned cash flow and the actual realisation. We have found that the new and extended functionalities of the TO-BE process enable quicker and more accurate cash flows forecasts for the future. We have come to the realisation that because there is less time consuming for the process execution and the elimination of manual operations we can save 466 hours per year, which could be used to carry out various analyses and prepare reports, which is also enabled in the reformed MFERAC information system, and which represents an added value for further forecasting of cash flows and the execution of simulations, taking into account certain event scenarios that may affect the liquidity of the national budget.

In addition to the advantages, the participants in the TO-BE process also named some weaknesses in their interviews. The reformed information system, where users or participants execute the process, seems to be non-transparent to $44 \%$ of users. $24 \%$ of users find the occasional slow operation of the information system where the process is being performed disturbing. One of the weaknesses that are indicated by $8 \%$ of users is the repeated selection of PU in the modules where the process is being carried out. Individual users also indicated some weaknesses of the modules where the process is being executed: difficulty in accessing tasks, too much scrolling, and clicking. Some of them do not see any added value of the reformed information system, they haven't received sufficient procedural instructions for the execution of the process, they are disturbed by errors in the information system, and the light emitted from the screen when the PLN module is opened.

Furthermore, we note that by introducing automatic data refresh or data sources, accurate information can be provided to management quickly and without data reconciliation at any time, for example on the cash balance on the budget sub-account on that day, at the end of the month or at the end of the year, which is one of the added values of the reformed process for the organisation. In addition, we found that the liquidity planning process of the national budget is a major contribution to cooperation with the process participants or users of the reformed information system, for they can help us give information with feedback on what process operations are supported well, where there are the so-called bottlenecks, and they can also suggest improvements. Apart from this, we note that the introduction of a user helpdesk provides the organisation with an integrated approach, where all participants in the examined processes cooperate, and exchange knowledge and experience. We found that the involvement of the information system users or participants in the examined process in the reform had a positive impact on the easier adoption of the changed workflow, and we as managers could obtain the accurate data or information timely, which is important for the planning of cash flows. 


\section{Discussion}

Business process management, which requires constant verification of the efficiency of business processes and, consequently, proper changes to business processes, poses a major challenge for most organizations, as they lack awareness that business process management can help them achieve flexibility. Flexibility means success (Goasduff, 2016), and this is also what we found through the study of the process, for we had to replace the existing support information system with a new one, which had to be adapted to meet the requirements necessary to execute the liquidity planning process of the national budget to carry out the process.

According to Harmon (2019), organisations that make steady improvements to business processes using available technology ensure consistent improvement in business through the results of optimized processes, which the examined organisation will be able to take into account in the further development of the information system that supports the execution of the examined process. According to Burlton (2001), processes should be seen as the organization's resources, much like people, facilities, and information. He says that the payment for good management of business processes is a success of the organisation. We can compare this to the conclusion of the research of the examined organisation that has also introduced processes management at the same time as the reform was introduced, and if it will continue to manage the processes well, success will be guaranteed.

Knowledge is a valuable asset of the organization. Dalkir (2017) says it is built into the products or services and integrated into the knowledge of employees, which we also found through the research of the examined organisation, for the process of reforming existing processes included the knowledge and the experience of the employees in various areas of expertise, based on which they were able to prepare, for example, the specifications of the requirements to reform the execution and propose appropriate solutions.

Laguna and Marklund (2019) note that human resources management is important and represents a process approach, which means that all employees know the structure of business processes. They also note that the transparency of process execution improves the understanding of employees about what their efforts mean and why their contribution to the organisation is important. In our study, this was reflected through the fact that not only particular members of the workgroup could participate in the reform, but also the users and other participants in the examined process, who were able to propose improvements based on their knowledge and experience.

By researching the liquidity planning process of the national budget we found, through our observation method and experience in daily involvement in the examined processes, that the processes are "living", which means that they are constantly changing. Therefore, adjustments in the business processes execution are also necessary, which is a concrete process that means that due to the huge amount of data and information, an appropriate 
support information system must be provided, which will allow for smooth management and processing of data.

Kovačič and Bosilij Vukšič (2005) define the reform of business processes as a detailed examination of the processes, business operations, and tasks carried out in the organization. They say that we then change the way we do business to increase efficiency, reduce costs and improve the quality of operations based on the analysis of business processes. (Kovačič and Bosilij Vukšić, 2005). In the organisation under examination we also first checked the situation of the existing process, where we identified and defined key operations, and then made proposals for changes based on the findings, which, as we found, reduced the costs and increased the efficiency of operations.

We found that the process mainly interweaves the communication flow between different information systems or databases of the examined organisation (MFERAC, SULP database, SULP auxiliary database), which are not interconnected, thus leading to many manual operations, which means more necessary data reconciliation, and data checks or controls of entered or imported or exported data. With the model of the reformed process, the exchange of data takes place via the single IS MFERAC, manual operations were replaced by automated service procedures carried out with each change transferred and displayed in real-time, which means less activity for IS users or participants. The elimination of manual inputs has the greatest positive effect on the improvement of the process. Kovačič and Bosilij Vukšić (2005) also say that one of the objectives is to simplify procedures by canceling unnecessary or duplicate operations of the process.

The process was reduced by an average of 50\%, which means EUR 3,394.80 lower the annual cost of the process. In the results of the effects of the improvements of the examined reformed process, we need to take into account the limitation that the reform is still underway, which means that the new support information system is still being developed and does not yet represent the final expected version that was planned at the beginning of the reform. Quirk (2019) also says that the goal is to optimise or streamline the organisation's business to execute business processes efficiently as quickly and with as few costs as possible.

With the end of manual data entries in the reformed process, the number of errors decreases by $72 \%$. Using the method of our observation and comparison of the information systems of the Ministry of finance, we were able to find that the bulk of the data entered manually in is in the existing process is now automatically directly transferred across information systems, which means less untimely reported data, which can have a positive impact on the liquidity planning process of the national budget.

By interviewing the users or participants of the information system in the examined process, we found that only $13 \%$ of respondents believe that the data are more accurate and transparent in the reformed process. However, by using the method of our observation 
and experience and by comparing data in the existing and reformed information system, we found that the discrepancies between the forecast liquidity plans and the actual realisation are $18 \%$ smaller, which for us, i.e. the cash flow managers, means more accurate data. We also noted that the introduction of an economic classification, which replaced the use of liquidity items, had an impact on more accurate data imported into the reformed information system from other existing data sources.

The maximum added value of the research is the reform of the business process that is bringing an end to manual operation to the organisation because this means saving the time that the participants in the examined process can use to produce various analyses and prepare reports that the reformed MFERAC information system enables, which represents additional added value in further forecasting cash flows and the execution of business plans while taking into account certain event scenarios, which may affect the liquidity of the national budget. In addition, we have already received some suggestions for improvements through the responses obtained from interviews of information system users or participants in the examined process, which can be taken into account in further development. We also found that the introduction of the helpdesk, and thus a rapid response in error resolution and customer support, has positive effects on the reform process. By getting feedback from users, we can quickly identify where the obstacles to the process are. By participating in the reform, users more easily get accustomed to the changing way of the execution of operations in the reformed process and helping the organization to discover solutions, which is an added value for the organization, because, on the one hand, it creates a friendly working environment for the user through improvements and, on the other hand, it has motivated employees and efficient and quality business.

The contribution of the research is in the systematic review, analysis, and findings from the existing and improved processes, which provide the organisation under examination as a basis for a reasonable further improvement of the underlying business processes. This case study is a contribution to the applied use of presented/used methodologies to introduce improvements in business processes in public as well as private organisations in Slovenia and more broadly in the EU and contributes to the development of the profession/science in terms of business process management.

\section{References}

1. Alkharouf, N.W., Jamison, D.C., and Matthews, B.F. (2005). Online analytical processing (OLAP): A fast and effective data mining tool for gene expression databases. Journal of Biomedicine and Biotechnology, 2, 181-188.

2. Burlton, R. (2001). Business process management: profiting from the process. Indianapolis: Sams Publishing.

3. Dalkir, K. (2017). Knowledge management in theory and practice. Cambridge: MIT Press. 
4. Laguna, M., Marklund, J. (2019). Business process modeling, simulation, and design. London: CRC Press.

5. Damius, N. (2009). Management poslovnih procesov: modeliranje, simuliranje, inovacija in izboljšanje. Ljubljana: Založba Vega.

6. Goasduff, L. (2016, March 9). BPM is critical to business transformation success. Gartner. Found June 8, 2020, at https://www.gartner.com/

7. smarterwithgartner/bpm-is-critical-to-business-transformation-success/

8. Harmon, P. (2019). Business process change: A business process management guide for managers and process professionals. Cambridge: Morgan Kaufmann Publishers.

9. Khan, R.N. (2004). Business process management: a practical guide. Florida: Meghan-Kiffer Press.

10. Smith, A., Bosilij Vukšić, V. (2005). Management poslovnih procesov: prenova in informatizacija poslovanja. Ljubljana: GV založba.

11. Ministry of Finance. (2018). Title of the internal material (internal material). Ljubljana: Ministry of Finance.

12. Netjes, M., Reijers, H.A., and van der Aalst, W.M. (2006). Supporting the BPM lifecycle with FileNet.

13. Rules on procedures for the execution of the budget of the Republic of Slovenia. Official Journal of the Republic of Slovenia No. 81/2016.

14. Wynn, M., De Weerdt, J., Hofstede, A., van der Aalst, W., Reijers, H., Adams, M., Ouyang, C., Rosemann, M., and Low, W.Z. (2013). Cost-aware business process management: A research agenda. In H. Deng and C. Standing (ed.), Proceedings of the 24th Australasian Conference on Information Systems (ACIS) (pp. 1-10). Melbourne: RMIT University. https://eprints.qut.edu.au/63411/1/ResearchAgendacameraready.pdf

\section{List of abbreviations}

DP (sl. državni parlament) - Slovene national parliament

DZ (sl. državni zbor) - national assembly

FURS (sl. Finančna uprava Republike Slovenije) - Financial Administration of the Republic of Slovenia

IS (s1. informacijski sistem) - information system

KLN (sl. korigiran likvidnostni načrt) - adjusted liquidity plan

LN (sl. likvidnostni načrt) - liquidity plan

MFERAC (sl. enoten računovodski sistem za izvršsevanje državnega proračuna) - unified accounting system for the execution of the national budget

PFN (sl. predlagatelji finančnega načrta) - the proposers of the financial plan

PLN (sl. predlog likvidnostnega načrta) - liquidity plan proposal

PU (sl. proračunski uporabnik) - budget user

SPU (sl. skupine proračunskih uporabnikov) - budget users' groups

SULP (sl. sistem za upravljanje likvidnosti proračuna) - budget liquidity management system 